\title{
ANALISIS KUALITAS LAYANAN WEBSITE GRAB MENGGUNAKAN METODE WEBQUAL DI AREA KOTA DENPASAR BALI
}

\author{
Putri Anggreni ${ }^{(1)}$ \\ I Made Wahyu Artha Wikrama ${ }^{(2)}$ \\ ${ }^{(1)(2)}$ Fakultas Ekonomi Universitas Mahendradatta \\ Email:gekcay@gmail.com
}

\begin{abstract}
Making a website so far only focused on the system, the look and content of the website content is presented regardless of the website user satisfaction, this study aims to determine the level of user satisfaction grab website. WebQual research method using 4.0 as well as the scale linkert as the study interval. WebQual is one method or technique of measuring the quality of a website based on the perception of the end user. 4.0 WebQual method is based on three dimensions of usability, information quality dimensions and dimensional quality of the interaction.

In the analysis process used tranches sample of respondents to 120 people from among the people who use the website grab. The study used a questionnaire directly in tertuls verbally and directly collected and processed data. The next stage is the analysis of data consisting of validity, reliability and judgment with linkert scale. On the validity of the test using the formula Pearson Bevariate while reliability test using Cronbach's alpha formula. In the assessment using the scale linkert with 4 scale interval.

Based on the research results obtained have an average total satisfaction very high value on the quality of the website grab the results in each of these dimensions WebQual method wherein the usability dimension produces an average score of 3.34, the dimensions of information quality and interaction quality 3,58 3, 45, in other words in the Likert scale interva include very satisfied. This study is useful as information as information to the grab to improve the quality of website services on an ongoing basis to improve user satisfaction grab website.
\end{abstract}

Keywords: Quality of Service, Website, Grab, WebQual 


\section{PENDAHULUAN}

Perkembangan teknologi beberapa tahun terakhir yang begitu cepat, membuat berbagai peluang bisnis melalui teknologi semakin menjanjikan. Manusia menciptakan teknologi untuk mendorong/mendukung kegiatan yang dilakukan oleh individu maupun perusahaan sehingga lebih efektif dan efisien Sudjana \& Rivai, 2015). Penerapan teknologi dan informasi menyebabkan perubahan dalam kebiasaan atau habit yang baru pada bidang bisnis. Seperti pemanfaatan media perdagangan perusahaan jasa menggunakan media internet yang saat ini tidak sulit dijangkau oleh semua kalangan. Dampak utama dalam penggunaan teknologi informasi dan komunikasi dalam bisnis adalah tingginya volume penggunaan internet. Di dunia pertumbuhan pengguna internet dari tahun ke tahun mengalami kenaikan hingga 200 juta pengguna dari tahun 2015 lalu ini menurut laporan State of Connectivity: A Report on Global Internet Access yang dibuat oleh Facebook yang berarti sekarang ada sekitar 3,4 miliar pengguna internet di dunia. Dilihat dari total populasi manusia yang mencapai 7,4 miliar, artinya internet sudah hampir digunakan oleh 50 persen penduduk Bumi.

\section{Internet Users in the World \\ by Regions - December 31, 2017}
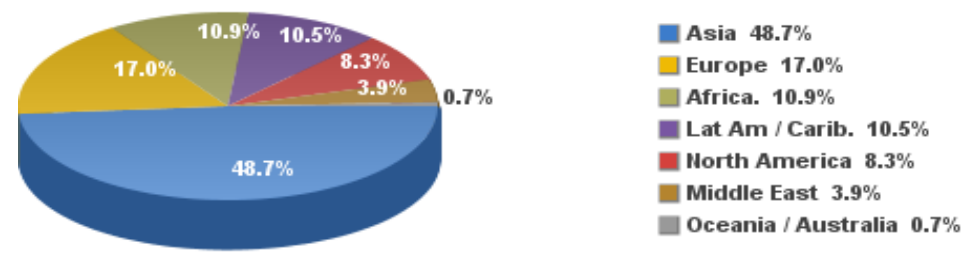

Source: Internet World Stats - www.internetworldstats.com/stats.htm

Basis: 4,156,932,140 Internet users in December 31, 2017

Copyright @ 2018, Miniwatts Marketing Group

Sumber: http://www.internetworldstats.com (diakses 31Desember 2017).

Gambar 1. Persentase pengguna pnternet di dunia 
Pada gambar 1 menunjukkan persentase pengguna internet di dunia yang terdiri dari 7 (tujuh) benua pada tahun 2017. Dari gambar tersebut dapat dilihat bahwa pengguna terbanyak berasal dari Asia sebanyak 48,7\% menurun 0,9\% dibanding tahun 2016 yaitu 49,6\%. Masih menurut data Internet World Stats, pengguna internet Asia saat ini mencapai 2 miliar jiwa dengan penetrasi 48,1\% dari total populasi sebesar 4 miliar jiwa. Hal tersebut dipengaruhi oleh kebangkitan asia sebagai kontribusi utama untuk populasi internet di dunia.

\begin{tabular}{|c|c|c|c|c|c|c|}
\hline & 2013 & 2014 & 2015 & 2016 & 2017 & 2018 \\
\hline 1. China* & 620.7 & 643.6 & 669.8 & 700.1 & 736.2 & 777.0 \\
\hline 2. US"* & 246.0 & 252.9 & 259.3 & 264.9 & 269.7 & 274.1 \\
\hline 3. India & 167.2 & 215.6 & 252.3 & 283.8 & 313.8 & 346.3 \\
\hline 4. Brazil & 99.2 & 107.7 & 113.7 & 119.8 & 123.3 & 125.9 \\
\hline 5. Japan & 100.0 & 102.1 & 103.6 & 104.5 & 105.0 & 105.4 \\
\hline 6. Indonesia & 72.8 & 83.7 & 93.4 & 102.8 & 112.6 & 123.0 \\
\hline 7. Russia & 77.5 & 82.9 & 87.3 & 91.4 & 94.3 & 96.6 \\
\hline 8. Germany & 59.5 & 61.6 & 62.2 & 62.5 & 62.7 & 62.7 \\
\hline 9. Mexico & 53.1 & 59.4 & 65.1 & 70.7 & 75.7 & 80.4 \\
\hline 10. Nigeria & 51.8 & 57.7 & 63.2 & 69.1 & 76.2 & 84.3 \\
\hline 11. UK $\cdot \cdot$ & 48.8 & 50.1 & 51.3 & 52.4 & 53.4 & 54.3 \\
\hline 12. France & 48.8 & 49.7 & 50.5 & 51.2 & 51.9 & 52.5 \\
\hline 13. Philippines & 42.3 & 48.0 & 53.7 & 59.1 & 64.5 & 69.3 \\
\hline
\end{tabular}

\begin{tabular}{|c|c|c|c|c|c|c|}
\hline 14. Turkey & 36.6 & 41.0 & 44.7 & 47.7 & 50.7 & 53.5 \\
\hline 15. Vietnam & 36.6 & 40.5 & 444 & 48.2 & 52.1 & 55.8 \\
\hline 16. South Korea & 40.1 & 40.4 & 40.6 & 40.7 & 40.9 & 41.0 \\
\hline 17. Egypt & 34.1 & 36.0 & 38.3 & 40.9 & 43.9 & 47.4 \\
\hline 18. Italy & 34.5 & 35.8 & 36.2 & 37.2 & 37.5 & 37.7 \\
\hline 19. Spain & 30.5 & 31.6 & 32.3 & 33.0 & 33.5 & 33.9 \\
\hline 20. Canada & 27.7 & 28.3 & 28.8 & 29.4 & 29.9 & 30.4 \\
\hline 21. Argentina & 25.0 & 27.1 & 29.0 & 29.8 & 30.5 & 31.1 \\
\hline 22. colombia & 24.2 & 26.5 & 28.6 & 29.4 & 30.5 & 31.3 \\
\hline 23. Thailand & 22.7 & 24.3 & 26.0 & 27.6 & 29.1 & 30.6 \\
\hline 24. Poland & 22.6 & 22.9 & 23.3 & 23.7 & 24.0 & 24.3 \\
\hline 25. South Africa & 20.1 & 22.7 & 25.0 & 27.2 & 29.2 & 30.9 \\
\hline Worldwide ${ }^{* *}$ & 2.692 .9 & $2,892.7$ & 3.072 .6 & 3.246 .3 & $3,419.9$ & $3,600.2$ \\
\hline \multicolumn{7}{|c|}{$\begin{array}{l}\text { Note: individuals of any age who use the internet from any location via any } \\
\text { device at least once per month" "excludes Hong Kong. "Forecast from Aug } \\
2014 ; \text { " * includes countries not listed } \\
\text { Source: eMarketer, Nov } 2014\end{array}$} \\
\hline
\end{tabular}

Sumber: https://kominfo.go.id (diakses 31 Januari 2017)

Gambar 2. Peringkat negara pengguna internet

Pada gambar 2 Indonesia masuk ke dalam 10 besar dengan menduduki peringkat ke 6 (enam) di dunia dalam hal jumlah pengguna internet. Populasi pengguna internet di Indonesia berkembang sangat pesat. Berdasarkan data yang dipublikasikan WeAreSocial, kini ada 88,1 juta orang Indonesia yang menggunakan internet dari total populasi 259 juta jiwa. Masyarakat Indonesia pun terpantau semakin lumrah menghabiskan waktunya dalam sehari untuk berselancar di dunia maya. Masih menurut data dari WeAreSocial, rerata orang Indonesia menggunakan internet per harinya lewat PC atau tablet ialah 4 jam 42 
menit. Sedangkan waktu yang dihabiskan untuk surfing di ponsel lebih sedikit, yakni 3 jam 33 menit saja.

Grab adalah salah satu layanan penyedia transportasi berbasis online. Indonesia menjadi pasar yang menggiurkan bagi para penyedia layanan transportasi berbasis aplikasi. Tak terkecuali bagi Grab (dahulu GrabTaxi), startup asal Malaysia yang mulai melebarkan sayapnya ke seluruh penjuru Asia Tenggara. Grab pertama kali menjejakkan kaki di pasar Indonesia pada Juni 2014 dengan layanan GrabTaxi. Seiring dengan popularitasnya yang semakin meluas, pada 2015 GrabTaxi melakukan ekspansi dengan merilis layanan ojek online pesaing Go-Jek, yakni GrabBike. Layanan ini pun bisa diterima dengan baik oleh masyarakat. Dan pada Juni 2015, barulah GrabTaxi merilis GrabCar di Bali. Lalu, pada Agustus 2015, GrabCar juga hadir di Jakarta. GrabCar merupakan layanan transportasi kendaraan roda empat berpelat hitam. Perusahaan Grab Indonesia memiliki layanan website yang berfungsi sebagai media untuk memberikan informasi bagi konsumennya mengenai jasa apa yang mereka jual. Dan dari website ini pihak Grab akan memperoleh feedback secara tidak langsung.

Berdasarkan data Top Brand Index (TBI), Grab Indonesia termasuk berada diurutan ke-2 TOP dalam kategori jasa transportasi online yaitu sebesar $14,7 \%$. Dan terlepas dari penghargaan di atas, kualitas layanan website grab ini bisa diukur dengan berbagai metode, salah satunya dengan metode Webqual, yaitu melakukan teknik pengukuran berdasarkan persepsi pengguna akhir. Webqual ini merupakan metode yang telah dikembangkan dari Servqual yang disusun oleh Parasuraman. Servqual banyak digunakan sebelumnya pada pengukuran kualitas 
jasa. Kualitas layanan website grab merupakan menjadi perhatian khusus dalam memberikan kualitas layanan yang lebih maksimal dari pihak Grab kepada konsumen atau pengguna website Grab. Dari hasil beberapa tanggapan konsumen tentang website Grab yang masih merasakan susahnya menggunakan website Grab dan jumlah pengunjung yang menurun karena adanya beberapa keluhan yang masih dirasakan oleh konsumen, dalam memenuhi kebutuhannya yang menggunakan jasa layanan website Grab, maka pihak Grab harus memperbaiki layanan website tersebut.

Menurut Pujawan (2017:97) kualitas pelayanan adalah sebagai hasil persepsi dan perbandingan antara harapan pelanggan dengan kinerja aktual layanan yang terdapat dua faktor utama yang mempengaruhi kualitas jasa, yaitu expected service (pengalaman yang diharapkan) dan perceived service (pelayanan yang diterima). Karena layanan yang dirasakan memiliki dampak terhadap tanggapan konsumen.

Berdasarkan latar belakang penelitian di atas, maka rumusan masalah dalam penelitian ini adalah: 1) Bagaimana pihak Grab memperoleh feedback terhadap website grab? 2) Bagaimana tanggapan konsumen terhadap website Grab?

Tujuan penelitian ini adalah: 1) memberikan feedback dari pengguna website Grab terhadap pihak yang bersangkutan dalam hal ini adalah dari Grab yang berkaitan dengan website Grab; 2) mengoptimalkan fitur serta menu yang terdapat di dalam website Grab agar dapat mengakomodir semua kebutuhan masyarakat yang berkaitan dengan kepuasan pengguna 
Menurut Lovelock dan Wright (2008:18-20) terdapat delapan komponen manajemen jasa terpadu, yaitu: 1) elemen produk merupakan semua komponen kinerja jasa yang menciptakan nilai bagi pelanggan; 2) tempat dan waktu merupakan keputusan manajemen tentang kapan, di mana dan bagaimana menyampaikan jasa kepada pelanggan; 3) proses adalah metode pengoperasian atau serangkaian tindakan tertentu, yang umumnya berupa langkah-langkah yang diperlukan dalam suatu urutan yang telah ditetapkan; 4) produktivitas dan kualitas (produktivitas mencangkup beberapa efesien pengubahan input jasa menjadi output yang menambah nilai bagi pelanggan. Sementara kualitas mencangkup sejauh mana suatu jasa memuaskan pelanggan dengan memenuhi kebutuhan, keinginan, dan harapan mereka); 5) orang meliputi karyawan atau terkadang pelanggan yang terlibat dalam proses produksi. Banyak jasa bergantung pada interaksi langsung dan pribadi antara pelanggan dan karyawan perusahaan. Sifat dan interaksi ini sangat mempengaruhi persepsi pelanggan terhadap kualitas jasa. Pelanggan sering menilai kualitas jasa yang mereka terima berdasarkan penilaian terhadap orang-orang yang menyediakan jasa tersebut; 6) promosi dan edukasi adalah semua aktivitas dan alat yang menggugah komunikasi yang dirancang untuk membangun preferensi pelanggan terhadap jasa dan penyedia jasa tertentu. Komponen ini memainkan tiga peran penting, yaitu: menyediakan informasi dan saran yang dibutuhkan, membujuk pelanggan sasaran tentang kelebihan suatu produk dan mendorong pelanggan untuk mengambil tindakan pada suatu waktu; 7) bukti fisik adalah petunjuk visual atau berwujud lainnya yang memberi bukti 
atas kualitas jasa; 8) harga dan biaya jasa lainnya meliputi pengeluaran uang, waktu dan usaha oleh pelanggan untuk membeli dan mengkonsumsi jasa.

Dari sekian banyak website yang ada di jagat maya, belum tentu semuanya dapat digolongkan sebagai website yang baik. Setidaknya ada beberapa kriteria yang perlu diperhatikan sehingga website dapat dikatakan sebagai website yang baik. Menurut Suyanto (2009:61-69), kriteria-kriteria yan harus diperhatikan tersebut yaitu: 1) Usability melibatkan pertanyaan "dapatkah user menemukan cara untuk menggunakan situs web tersebut dengan efektif atau usibility adalah sebagai suatu pengalaman pengguna berinteraksi dengan aplikasi atau situs web sampai pengguna dapat mengoprasikannya dengan mudah dan cepat; 2) Sistem Navigasi (struktur) membantu pengunjung untuk menemukan jalan yang mudah ketika menjelajahi web. Navigasi dapat ditampilkan dalam berbagai media, yaitu teks, image, atau animasi. Adapun syarat navigasi yang baik yaitu mudah dipelajari, tetap konsisten, memungkinkan feedback, mucul dalam konteks, menawarkan alternatif lain, memerlukan perhitungan waktu dan tindakan, menyediakan pesan visual yang jelas, menggunakan label yang jelas dan mudah dipahami dan mendukung tujuan dan perilaku user. 3) Graphic design (Desain Visual). Kepuasan visual seorang user secara subjektif melibatkan bagaimana desainer visual situs web tersebut membawa mata user menikmati dan menjelajahi situs web dengan melalui layout, warna bentuk dan tipografi. Grafik membuat halaman menjadi indah tetapi bisa juga memperlambat akses dengan semakin besarnya ukuran file. Desain yang baik setidaknya memiliki komposisi warna yang baikdan konsisten, layout grafik yang konsisten, teks yang mudah dibaca, 
penggunaan grafik yang memperkuat teks, dan secara keseluruhan membentuk suatu pola yang harmonis; 4) Contents yang baik akan menarik relevan dan pantas untuk target audiens situs web tersebut. Gaya penulisan dan bahsa yang dipergunakan harus sesuai dengan web dan target audien. Hindari kesalahn dalam penulisan termasuk tata bahasa dan tanda baca di tiap halaman, header, dan judulnya. Buat daftar penjelasan untuk istilah-istilah khusus. Konten harus relevan dengan tujuan situs. Jika ada konten yang berbentuk multimedia. Usahakan berhubungan dengan isi situs web; 5) Compatibility. Situs web kompatibel dengan berbagai perangkat tampilannya (browser), harus memberikan alternatif bagi browser yang tidak dapat melihat situsnya; 6) Loading Time. Sebuah penelitian yang dilakukan oleh Zona Research (April 1999) menyatakan bahwa 80\% pengunjung akan menutup browser bila halaman web yang ia buka tidak tampil dalam tujuh samapi delapan detik. Penelitian Jupiter media Metrix (Sep 2001Amerika Serikat) mengatakan bahwa 40\% pengunjung akan kembali mengunjungi situs yang lebh cepat. Sebuah situs web yang tampil lebih cepat kemungkinan besar akan kembali dikunjungi, apalagi bila dengan konten dan tampilan yang menarik; 7) Functionality. Seberapa baik sebuah situs web bekerja dari aspek teknologinya, ini bisa melibatkan programmer dengan scrip-nya, misalnya HTML (DHTML), PHP, ASP, Coldfusion, CGI, dan SSI; 8) Accesibillity. Halaman web harus bisa dipakai oleh setiap orang, baik anak-anak, orang tua, dan orang muda termasuk orang cacat. Ada berbagai hambatan yang ditemui dari sisi pengguna untuk bisa menikmati halaman situs web itu. Untuk hambatan fisik, bagaimana memaksimalkan penggunaan konten ketika satu atau lenih indra penglihatan. 
Selain itu juga hambatan infrastruktur, seperti akses internet yang lambat, spesifikasi komputer, penggunaan browser, yang dapat mempengaruhi akses seseorang; 9) Interactivity adalah apa yang melibatkan pengguna situs web sebagai user experience dengan situs web itu sendiri. Dasar dari interaktivitas adalah hyperlinks (links) dan mekanisme feedback. Gunakan hyperlink untuk membawa pengunjung ke sumber berita, topik lebih lanjut, topik terkait, atau lainnya. Seperti link yang berbunyi more info about this, glossary, dan related links. Sedangkan mekanisme feedback, contohnya adalah critiques, comments, question, pooling/survey. Bentuk lainnya juga bisa seperti search (pencarian intra situs), tools (perangkat yang digunakan pengunjung ntuk mencapai tujun mereka datang ke situs kita), Game, chat, dan forum diskusi.

Menurut Slabey dalam Wahidin (2013), webqual adalah pengukuran berdasarkan quality function deployment (QFD). Webqual adalah suatu pengukuran untuk mengukur kualitas dari sebuah website berdasarkan instrumentinstrumen penelitian yang dapat dikategorikan kedalam tiga variabel yaitu: usability, information quality, dan services interaction. Kesemuanya adalah pengukuran kepuasan konsumen atau user terhadap kualitas dari website tersebut.

Webqual sudah mulai dikembangkan sejak tahun 1998 dan telah mengalami beberapa interaksi dalam penyusunan dimensi dan butir pertanyaan. Webqual 4.0 disusun berdasarkan tiga dimensi, yaitu: 1) Usability; 2) Kualitas interaksi (information quality); 3) Interaksi layanan (service interaction).

Persepsi penggguna tentang suatu sistem informasi yang baik adalah sebuah sistem di mana pengguna merasa puas dengan kualitas dari website. 
Kualitas ini termuat dalam tiga dimensi dari Webqual versi 4.0. Penelitian sebelumnya menyarankan bahwa dimensi Webqual dapat memprediksi kepuasan pengguna dan maksud pengguna dalam mengunakan kembali website.

\section{METODE PENELITIAN}

Dalam hal ini adapun definisi operasional dari variabel yaitu kualitas layanan adalah segala bentuk aktivitas yang dilakukan oleh perusahaan guna memenuhi harapan konsumen. Pelayanan dalam hal ini diartikan sebagai jasa atau service yang disampaikan oleh pemilik jasa yang berupa kemudahan, kecepatan, hubungan, kemampuan dan keramahtamahan yang ditujukan melalui sikap dan sifat dalam memberikan pelayanan untuk kepuasan konsumen. Kualitas pelayanan (service quality) dapat diketahui dengan cara membandingkan persepsi para konsumen atas pelayanan yang nyata-nyata mereka terima/peroleh dengan pelayanan yang sesungguhnya mereka harapkan/inginkan terhadap atribut-atribut pelayanan suatu perusahaan. Kualitas layanan dalam penelitian ini dapat dilihat dari bagaimana kepuasan pengguna dari Website grab ini, dinilai dari feedback yang diterima oleh pihak grab, tanggapan konsumen terhadap website grab dan dalam memenuhi kebutuhan konsumennya.

Populasi dalam penelitian ini adalah mengambil populasi berdasarkan jumlah pengguna website Grab pada tahun 2017 yang dimana setiap bulannya terdapat 50 orang, jadi total keseluruhan di tahun 2017 sebanyak 600 orang.

Jenis teknik sampling yang digunakan adalah Simple Random Sampling yaitu teknik untuk mendapatkan sampel yang langsung dilakukan pada unit sampling. Maka setiap unit sampling sebagai unsur populasi yang terpencil 
memperoleh peluang yang sama untuk menjadi sampel atau untuk mewakili populasinya. Penelitian ini menggunakan sampel sebanyak 120 orang atau $20 \%$ dari jumlah populasi yaitu 600 orang

Penelitian ini berlokasi di kantor cabang Grab Bali yang beralamat di Jl. Imam Bonjol No.555A Denpasar, Bali dan di seputaran jalan Denpasar dan Badung yang mencangkup jalur aktivitas Grab.

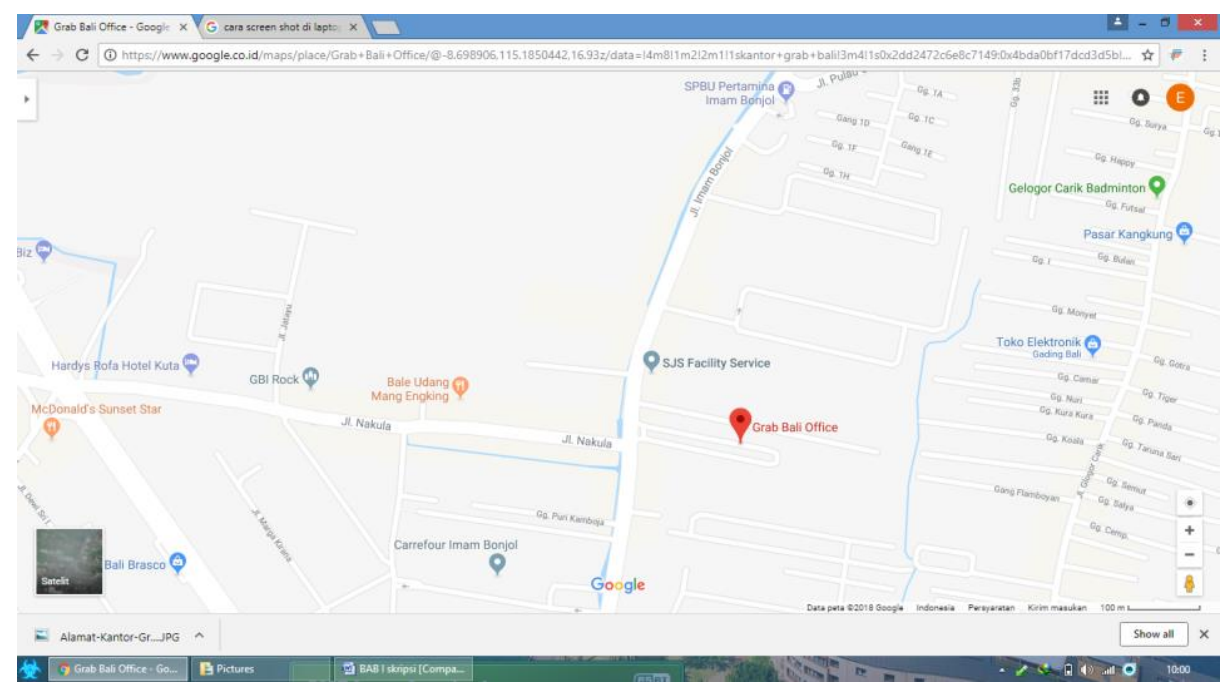

Gambar 3. Peta Lokasi Kantor Grab Bali

\section{HASIL PENELITIAN DAN PEMBAHASAN}

Dari hasil analisis yang di dapatkan pada tahapan uji validitas, uji reliabilitas, distribusi kualitas layanan, dan instrumen rata-rata skor skala likert yang telah dilakukan, maka dimensi dari metode webqual ini yaitu usability, Information quality, dan Interactoin quality mempengaruhi kepuasan penggunannya secara signifikan terhadap kepuasan pengguna, dilihat dari feedback yang diterima oleh pihak grab, tanggapan konsumen terhadap Website Grab dan pemenuhan dalam kebutuhan pengguna website Grab. Oleh sebab itu 
pembahasan tentang masing-masing dimensi metode webqual akan dibahas berikut:

\section{Kualitas Layanan Website Grab (Usability)}

Dari hasil analisis diatas menunjukan bahwa pada dimensi usability ini mempunyai hasil positif dan signifikan terhadap kepuasan pengguna website Grab dengan menggunakan metode webqual, pertama bisa dilihat dari hasil distribusi frekuensi kualitas layanan website Grab yang dimana dari hasil kuesioner yang disebar ke 120 responden didapatkan hasil frekuensi yang memilih sangat puas yaitu sebanyak 52 dengan persentase 43,3\% dan yang memilih atau menyatakan frekuensi puas yaitu sebanyak total 68 dengan persentase 56,7\%. Jadi sebagian besar pengguna puas dengan kualitas layanan website grab pada dimensi (usability) yaitu 56,7\% dari segi distribusi frekuensinya.

Selanjutnya yang kedua dilihat dari hasil instrumen rata-rata skor pada skala likert pada tingkat kepuasan konsumen dimensi usability dimana memiliki total rata-rata interval skor skala likert dengan jumlah 3,34 dengan responden yang valid sebanyak 30 dari total 120 responden, yang artinya 30 responden ini mewakili jawaban atau tanggapan dari total 120 responden tersebut. Dari masingmasing deskripsi indikator memiliki jumlah skor atau mean $3,25 \leq \mathrm{X} \leq 4$ yang berarti bahwa pengguna website Grab ini sangat puas atas kualitas layanan website Grab pada dimensi Usability yang memiliki skor rata-rata 3,34 (sangat puas). Jadi dapat dikatakan secara keseluruhan, konsumen sangat puas atas kualitas layanan website Grab dengan metode wequal dari segi dimensi Usability. 


\section{Kualitas Layanan Website Grab (Information quality)}

Hasil analisis menunjukan bahwa pada dimensi Information quality mempunyai hasil positif dan signifikan terhadap kepuasan pengguna website Grab dengan menggunakan metode webqual, pertama bisa dilihat dari hasil distribusi frekuensi kualitas layanan website Grab yang dimana dari hasil kuesioner yang disebar ke 120 responden didapatkan hasil frekuensi yang memilih sangat puas yaitu sebanyak total 43 dengan persentase $35,8 \%$ dan yang memilih atau menyatakan frekuensi puas yaitu sebanyak total 77 dengan persentase $64,2 \%$. Jadi sebagian besar puas dengan kualitas layanan website grab pada dimensi (Information Quality) yaitu 64,2\% dari segi distribusi frekuensinya.

Yang kedua dilihat dari hasil instrumen rata-rata skor pada skala likert pada tingkat kepuasan konsumen dimensi Information Quality dimana memiliki total rata-rata interval skor skala likert dengan jumlah 3,58 dengan responden yang valid sebanyak 30 dari total 120 responden, yang artinya 30 responden ini mewakili jawaban atau tanggapan dari total 120 responden tersebut. Dari masingmasing deskripsi indikator memiliki jumlah skor atau mean 3,25 $\leq X \leq 4$ yaitu yang berarti bahwa pengguna website Grab ini sangat puas atas kualitas layanan website Grab pada dimensi Information Quality yang memiliki skor rata-rata 3,58 (sangat puas). Jadi dapat dikatakan secara keseluruhan, konsumen sangat puas atas kualitas layanan website Grab dengan metode wequal dari segi dimensi Information Quality. 


\section{Kualitas Layanan Website Grab (Interactoin Quality)}

Hasil analisis menunjukan bahwa pada dimensi Interactoin Quality mempunyai hasil positif dan signifikan terhadap kepuasan pengguna website Grab dengan menggunakan metode webqual, bisa dilihat dari hasil distribusi frekuensi kualitas layanan website Grab yang dimana dari hasil kuesioner yang disebar ke 120 responden didapatkan hasil frekuensi yang memilih sangat puas yaitu sebanyak total 60 dengan persentase 50,0\% dan yang memilih atau menyatakan frekuensi puas yaitu sebanyak total 60 dengan persentase 50,0\%. Jadi sebagian sangat puas dengan kualitas layanan website grab pada dimensi (Interactoin Quality) yaitu 50,0 \% dan sebagian puas dengan kualitas layanan website grab pada dimensi (Interactoin Quality) yaitu 50,0\%.

Selanjutnya hasil instrumen rata-rata skor pada skala likert pada tingkat kepuasan konsumen dimensi Interactoin Quality dimana memiliki total rata-rata interval skor skala likert dengan jumlah 3,45, dengan responden yang valid sebanyak 30 dari total 120 responden, Dari masing-masing deskripsi indikator memiliki jumlah skor atau mean $3,25 \leq \mathrm{X} \leq 4$ yaitu 3,58 (sangat puas). Jadi dapat dikatakan secara keseluruhan konsumen sangat puas atas kualitas layanan website Grab dengan metode wequal dari segi dimensi Interactoin Quality.

\section{Analisis Tanggapan Balik (Feedback) Mengenai Website Grab Kepada Pihak Grab}

Dari semua hasil analisis yang dilakukan, dapat ditemukan bahwa tanggapan balik (feedback) pengguna dari website Grab kepada pihak grab ini sangat puas dengan kualitas layanan website Grab dengan metode webqual yang 
dimana dapat diukur atas 3 dimensi yang ada di dalam metode webqual tersebut yaitu Usability, Information Quality, dan Interaction Quality menunjukan hasil persentase frekuensi yang sangat positif dan signifikan menunjukan mayoritas pengguna website Grab sangat puas dengan kualitas layanan yang di sediakan ditambah lagi dari perhitungan instrumen rata-rata skor dari kuesioner yang menggunakan interval skala likert yang menghasilkan dari 30 responden yang mengisi kuesioner yang dinyatakan valid dari total 120 responden, skor rata-rata menunjukan bahwa pengguna website grab dilihat dari masing-masing dimensi yang menunjukan kategori $3,25 \leq X \leq 4$ yaitu pengguna atau konsumen sangat puas.

Didukung juga dengan pertanyaan dari kuesioner yang menanyakan bagaimana tanggapan balik (feedback) mengenai website grab kepada pihak grab?, yang secara keseluruhan disimpulkan bahwa tanggapannya positif untuk website grab ini karena sudah memberikan akses untuk mempermudah dalam mencari informasi tentang grab, kontennya menarik dan mudah untuk digunakan oleh masyarakat awam. Jadi dapat dikatakan tanggapan balik untuk pihak grab ini positif.

\section{Analisis Tanggapan Konsumen Terhadap Website Grab}

Dari semua hasil analisis yang dilakukan, dapat ditemukan bahwa tanggapan konsumen terhadap website Grab ini sangat puas dengan kualitas layanan website Grab dengan metode webqual yang dimana dapat diukur atas 3 (tiga) dimensi yang ada di dalam metode webqual tersebut yaitu Usability, Information Quality, dan Interaction Quality menunjukan hasil persentase 
frekuensi yang sangat positif dan signifikan menunjukan mayoritas pengguna website Grab sangat puas dengan kualitas layanan yang di sediakan ditambah lagi dari perhitungan instrumen rata-rata skor dari kuesioner yang menggunakan interval skala likert yang menghasilkan dari 30 responden yang mengisi kuesioner yang dinyatakan valid dari total 120 responden, skor rata-rata menunjukan bahwa pengguna website grab dilihat dari masing-masing dimensi yang menunjukan kategori 3,25 $\leq X \leq 4$ yaitu pengguna atau konsumen sangat puas.

Didukung juga dengan pertanyaan dari kuesioner yang menanyakan bagaimana tanggapan anda mengenai website Grab ini?, yang secara keseluruhan disimpulkan bahwa tanggapannya positif untuk website grab ini karena telah membantu dalam mengaplikasikan aplikasi Grab dengan mudah sehingga para pengguna website Grab terbantu dalam menggunakannya. Jadi dapat dikatakan tanggapan pengguna terhadap website Grab ini positif

\section{Analisis Website Grab Dalam Memenuhi Kebutuhan Konsumen}

Dari semua hasil analisis yang dilakukan, dapat ditemukan bahwa website grab dalam memenuhi kebutuhan konsumen ini sudah sangat puas dengan kualitas layanan website Grab dengan metode webqual yang dimana dalam memenuhi kebutuhan penggunanya, dapat diukur atas 3 dimensi yang ada di dalam metode webqual tersebut yaitu Usability, Information Quality, dan Interaction Quality menunjukan hasil persentase frekuensi yang sangat positif dan signifikan menunjukan mayoritas pengguna website Grab sangat puas dengan kualitas layanan yang di sediakan ditambah lagi dari perhitungan instrumen rata-rata skor dari kuesioner yang menggunakan interval skala likert yang menghasilkan dari 30 
responden yang mengisi kuesioner yang dinyatakan valid dari total 120 responden, skor rata-rata menunjukan bahwa pengguna website grab dilihat dari masing-masing dimensi yang menunjukan kategori $3,25 \leq \mathrm{X} \leq 4$ yaitu pengguna atau konsumen sangat puas.

Ditambah juga dengan pertanyaan dari kuesioner yang menanyakan apakah website Grab ini telah memenuhi kebutuhan anda?, dan secara keseluruhan disimpulkan bahwa tanggapannya positif untuk website grab ini karena kebanyakan atau mayoritas menjawab website Grab ini telah membantu dalam kebutuhan sehari-hari para penggunanya dimana mereka yang hendak bepergian jika tidak ada kendaraan, juga dalam pemenuhan konsumsi mereka dengan bisa langsung membuka aplikasi Grab tersebut melalui layanan website grab ini dan juga dalam berbisnis online yang bisa menggunakan layanan kurir grab (express) yang bisa mengantarkan barang ke kosumen pengguna layanan tersebut. Jadi dapat dikatakan website Grab dalam memenuhi kebutuhan konsumen ini di jawab dengan positif.

Berdasarkan perumusan hipotesa yang dibuat untuk analisis kulitas layanan website grab menggunakan metode webqual ini adalah bahwa kualitas layanan website grab diduga mempengaruhi terhadap kepuasan pengguna website grab. Setelah penulis melakukan analisis bahwa terdapat kesusaian antara hipotesa (dugaan sementara) yang dibuat, dengan hasil yang di peroleh oleh penulis atau dengan kata lain hipotesa (dugaan sementara) sejalan dengan hasil analisis penulis yang menunjukan bahwa tingkat kepuasan pengguna website grab dalam kategori sangat puas. 


\section{SIMPULAN}

Berdasarkan hasil penelitian dan pembahasan yang telah diuraikan, kesimpulan dari penelitian ini adalah sebagai berikut:

1. Kualitas layanan website grab dengan 3 dimensi metode webqual yaitu Usability, Information Quality, dan Interaction Quality berpengaruh positif dan signifikan dilihat dari hasil perhitungan instrumen rata-rata skor dari kuesioner yang menggunakan interval skala likert yang menghasilkan kategori 3,25 $\leq \mathrm{X} \leq$ 4 (sangat puas)

2. Tanggapan balik (feedback) mengenai website grab kepada pihak grab menghasilkan rata-rata tanggapan yang positif karena seperti yang sudah di bahas karena sudah memberikan akses untuk mempermudah dalam mencari informasi tentang grab, kontennya menarik dan mudah untuk digunakan oleh masyarakat awam .

3. Tanggapan konsumen terhadap website grab juga menghasilkan tanggapan yang positif karena bisa dilihat dari seluruh jawaban dari kuesioner yang telah di analisis bahwa telah membantu dalam mengaplikasikan aplikasi Grab dengan mudah sehingga para pengguna website Grab terbantu dalam menggunakannya.

4. Website Grab Dalam Memenuhi Kebutuhan Konsumen menghasilkan tanggapan yang positif, karena jawaban atau tanggapan rata-rata pengguna yaitu membantu dalam kebutuhan sehari-hari para penggunanya baik itu dalam layanan transportasi, makanan (food), dan kurir (express). 
Saran yang bersifat membangun untuk kualitas layanan website grab menggunakan metode webqual sebagai berikut :

1. Kualitas layanan website grab dengan 3 (tiga) dimensi metode webqual yaitu Usability, Information Quality, dan Interaction Quality sebaiknya di pertahankan atau ditingkatkan guna untuk mempertahankan persepsi pengguna website grab yang sudah merasa sangat puas dengan kegunaannya, kualitas informasinya, dan kualitas intaraksi yang terdapat padat layanan website grab.

2. Pihak grab agar mempertahankan tanggapan yang sudah positif dari pengguna website grab. Juga agar memperbahrui fitur dan konten yang ada dalam website grab agar pengguna semakin tertark dalam penggunaan layanan website grab ini.

3. Sebaiknya dari segi pemenuhan kebutuhan pengguna atau konsumen agar perlu ditambahkan lagi layanan yang bisa lebih meningkatkan kepuasan pengguna menggunakan website grab ini tidak hanya fokus pada 3 layaanan yang ada pada saat ini yaitu transportasi, makanan (food), dan kurir (express). Agar nantinya tidak kalah saing dengan saingan yang bergerak pada pelayanan jasa yang sama, juga agar bisa lebih berkembang dengan penambahan dari layananlayanan yang nantinya semakin memenuhi kebutuhan dari pengguna yang nantinya bisa membuat lebih maju dari kualitas layanan website grab ini dengan menggunakan metode webqual.

\section{DAFTAR PUSTAKA}

Christoper Lovelock \& Lauren K Wright. 2007. Manajemen Pemasaran Jasa, PT. Indeks, Indonesia.

Tjiptono, Fandy \& Chandra, Gregorius. 2012. Pemasaran Strategik. Yogyakarta: Penerbit ANDI. 
Johnson \& Christensen. 2012. Educational Research: Quantitative, Qualitative and Mixed Approaches. $4^{\text {th }}$ Edition. SAGE Publications.

Pujawan. 2017. Supply Chain Management. Yogyakarta: Andi Pbublisher.

Sudjana, Nana \& Rivai, Ahmad. 2015. Teknologi Pengajaran. Jakarta: Sinar Baru Algesindo.

Sugiyono. 2007. Metode Penelitian Kualitatif dan R\&D. Bandung: Alfabeta. . 2010. Metode Penelitian Pendidikan Pendekatan Kuantitatif, Kualitatif dan $R \& D$. Bandung: Alfabeta.

2012. Metode Penelitian Pendidikan Pendekatan Kuantitatif, Kualitatif dan $R \& D$. Bandung: Alfabeta.

2013. Metode Penelitian Pendidikan Pendekatan Kuantitatif, Kualitatif dan R\&D. Bandung: Alfabeta.

2014. Metode Penelitian Pendidikan Pendekatan Kuantitatif, Kualitatif dan $R \& D$. Bandung: Alfabeta.

Sukmadinata. 2009. Metode Penelitin Pendidikan. Bandung: Remaja Rosdakarya.

Wahidin, A. 2013. Analisa Kepuasan Mahasiswa Terhadap Website Universitas Negeri Yogyakarta (UNY). Yogyakarta: Universitas Negeri Yogyakarta (UNY).

https://andalforsharing.wordpress.com/2015/04/14/webqual/ diakses pada tanggal 31 Desember 2017.

https://kominfo.go.id diakses pada tanggal 31 Desember 2017. 
